\title{
Teaching principal plate tectonic processes by means of analogue modeling
}

\author{
Hans Peter STEYRER* \\ University of Salzburg, Department of Geography \& Geology, Salzburg, A-5020, Austria
}

Received February 2009; accepted March 2009

Available online June 2009

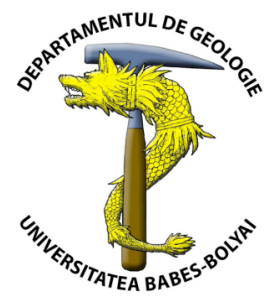

\begin{abstract}
Analogue sand models have been used to demonstrate, how the principal plate tectonic processes work. A simple and versatile sandbox was built and used for the experiments. The principle of this apparatus was suggested by F. K. Lehner with a passive backstop and a basal mylar sheet, which is pulled underneath for studies of compressional tectonics. Boundaries of divergence can be modeled by turning back the direction of movement of the mylar sheet and transform faults by dividing the mylar sheet into a moving and a stationary half. The three principal kinds of plate boundaries can be modeled with single layer sand-packs producing grabens, thrusts and strike slip faults. The results can be correlated with geological structures in nature. Sandbox experiments can also be run between glass sidewalls. Observations can be made through the glass enabling the sequential development of faults and structures to be analyzed. It is suggested, that lessons learned from he models are used for introductory geology courses at universities or high schools.
\end{abstract}

Key words: analogue modeling, plate tectonics, teaching.

\section{INTRODUCTION}

Plate tectonics works on Earth because of the rigidity of the lithosphere, which enables plates with horizontal dimensions of thousands of kilometers to move as distinct mechanical units with the speed of fingernail-growth. The dimensions of space and time are far beyond ones perception (maybe this is the reason, why this concept, which unifies so much of geological thought, came so late in the history of the subject).

According to the relative motions of adjacent plates, three principal kinds of plate boundaries can be defined: boundaries of divergence or spreading, boundaries of convergence and transform faults. This seems simple, but "there are phenomena, which, though being made up of well-understood simple systems, are so complicated as a whole as to render complete mathematical analysis difficult or impossible". This sentence is the opening of the classical paper on the theory of scale models in geology (Hubbert, 1937). Several decades later, analogue models are well accepted for research on natural systems at laboratory scale, using analogue materials such as sand and clay as brittle material analogue and wax, honey, beans and many other strange materials for simulating ductile/plastic behavior.

Horsfield (1977) showed that the rheological properties of moderately cohesive sediments could be simulated with dry sand after scaling down by a factor of between 1:10 000 and 1:100 000. Dry sand has an angle of internal friction of $\Phi=30-32^{\circ}$, which is similar to that determined for brittle sedimentary rocks in the upper continental crust. Fortunately the very low cohesive strength of dry sand makes the models essentially strain-rate independent, and allows deformation experiments to be performed over a reasonable length of time. Millions of years of tectonic deformation in sedimentary rocks are commonly simulated during hours or even less in so-called sandbox experiments.

An innovative sandbox apparatus was suggested by F. K. Lehner in the 1970s (pers. comm., Fig. 1). A description of this apparatus and first modeling results are referred by Horsfield (1977). This construction, let's call it Lehner's sandbox, was a great successs throughout the world of analogue modeling ever since and has been used by many working groups (e.g., Liu et al., 1992; Storti and McClay, 1995; Horner and Steyrer, 2005).

However, Lehner's sandbox can be used not only for modeling of compressional tectonics (boundaries of convergence in the plate tectonic dimension), but also for boundaries of divergence, simply by turning back the direction of movement of the mylar sheet (Fig. 2) and transform faults by dividing the mylar sheet into a moving and a stationary half (Fig. 3). The three principal kinds of plate boundaries can be modeled with single layer sandpacks producing grabens, thrusts and strike slip faults, and results can be correlated with geological structures in nature.

The use of lighting at low angle to the surface highlights any visible faults and eventual photographs of this, which aid in establishing the order that faults and structures are initiated within the model.

Sandbox experiments can also be run between two glass sidewalls. For experiments of this type, alternating layers of colored sand are carefully sieved. Observations can be made through the glass sidewall enabling the sequential development of faults and structures to be analyzed. 


\section{LEHNER'S SANDBOX AND PROCEDURE OF EXPERIMENTS}

The principle of the apparatus was suggested by F. K. Lehner with a passive backstop and a basal mylar sheet (P.V.C. foil), which is pulled underneath for studies of compressional tectonics. The arrangement with the fixed backstop turned out to have great advantages concerning the size of the apparatus $(80 \times 50 \mathrm{~cm}$ effective area, overall size $100 \times 60 \mathrm{~cm}$ ) and documentation of the deformation area. In addition to the original apparatus, a wheel-driven device (Fig. 1) can be fixed below the model casing to enable, for example, extension of a wide area by tilting-induced gravitational gliding.

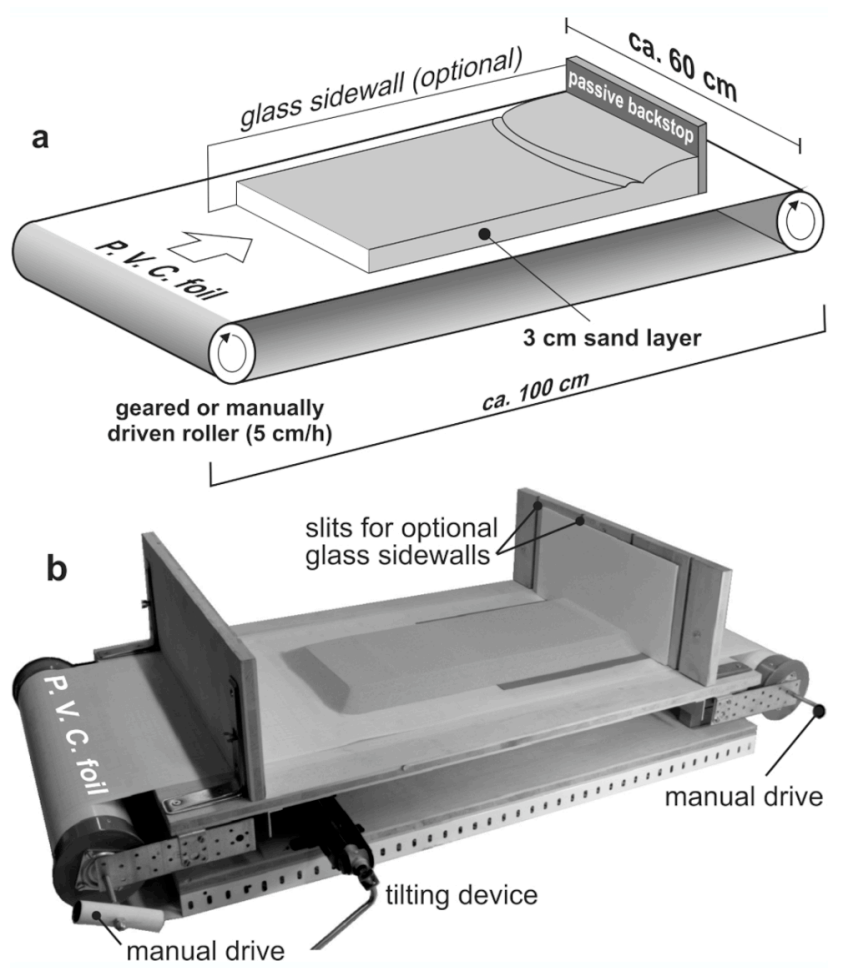

Fig. 1 a. Sketch of Lehner's sandbox. The box can be used without glass walls bounding the experimental area or with glass sidewalls. In the second case, the use of sand with different colors enables one to watch deformational processes in "real time" in plan view and contemporaneously in cross sectional view (compare Fig. 5); b. Photograph of the box, which can be built by a skillful (amateur) craftsman within a few hours and needs no expensive materials.

The box can be built by a skilful (amateur) craftsman within a few hours and needs no expensive materials (at least, when a manual drive of the P.V.C. foil is used), these are important requirements for university institutes or high schools! It can be used without glass walls bounding the experimental area or with glass sidewalls. In the second case, the use of sand with different colors enables one to watch deformational processes in plan view and contemporaneously in cross sectional view.

The appropriate analogue material for the upper crust dry cohesionless sand - is also easy to obtain: quartz-sand with grain sizes ranging from about $125-250 \mu$ is a common material in construction trade-shops. Colored sand can easily be produced by impregnating it with thinned Indian ink of the desired color, drying and sieving.

\section{EXTENSION: HORST AND GRABEN STRUCTURES AND RIFTS}

A rift is a place where the Earth's crust and lithosphere are being pulled apart. Typical features are a central-linear down-faultet segment, called a graben, with parallel normal faulting and rift-flank uplifts on either side forming a rift valley. A few prominent examples are Great Rift Valley in Africa (Braile et al., 1995), Lake Baikal - the bottom of which is the deepest continental rift on the earth (Galazi, 1993), the Rio Grande Rift in the southwestern US (Keller and Baldridge, 1999), the Oslo graben in Norway (Olaussen et al., 1994) and the Rhine Graben in Germany and France (Rotstein et al., 2006).

In the extensional experiment, a cardboard is attached to the backstop ("fixed" area in Fig. 2) and the foil is pulled beneath this area. After a few millimeters of movement a single graben bordered by parallel faults develops that widens and deepens in the course of the experiment. As in nature, the result is a downthrown block of land producing a valley with a distinct scarp on each side: the whole setting is indicative of tensional forces and crustal stretching.
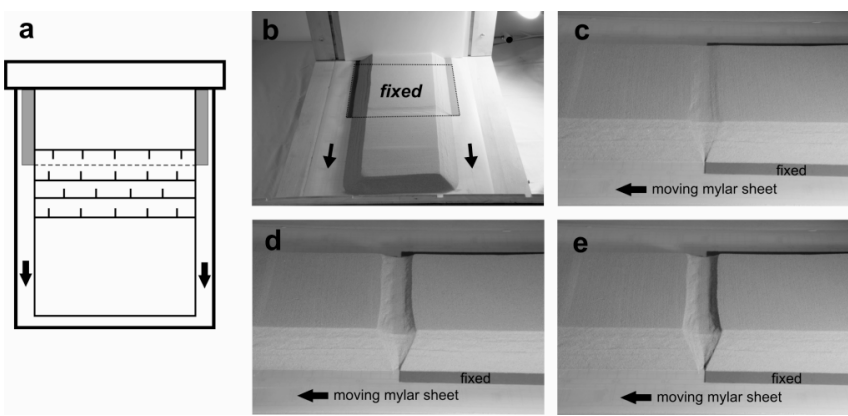

Fig. 2 a. Scheme for a model of crustal extension and development of Horst-and-Graben structures; b. Oblique view parallel to the evolving graben, $5 \mathrm{~cm}$ sandcake, lighting at low angle to the surface highlights the visible faults; c. Same experiment as in $b$, but oblique view perpendicular to the graben, after $0.5 \mathrm{~cm}$ extension; $\mathbf{d}$. same experiment, after $1 \mathrm{~cm}$ extension; e. same experiment, after $1.5 \mathrm{~cm}$ extension.

\section{STRIKE SLIP FAULTS}

Major strike-slip faults in continental rocks are typically hundreds of kilometers long, dip steeply and have a dominant strike-slip displacement. Examples include the Alpine Fault in New Zealand (Norris and Cooper, 2003), the Anatolian Fault in Turkey (Şengör, 1979), the Great Glen Fault in Scotland (Stewart et al., 2001) and, last, but not least, the San Andreas fault (Powell et al., 1993).

A model of strike slip faulting can be built by dividing the base of the sandcake into a "fixed" area and the moving foil (Fig. 3). The fixed area is simply achieved by attaching a cardboard to the fixed backstop.

The most conspicuous major structures associated with wrench faults are regional systems of fractures approximately parallel with, and commonly branching off, the main present-day fault - features that typically evolve in model shear zones, too (several generations of Riedel shears, Y-shears and splays, see Fig. 3). 

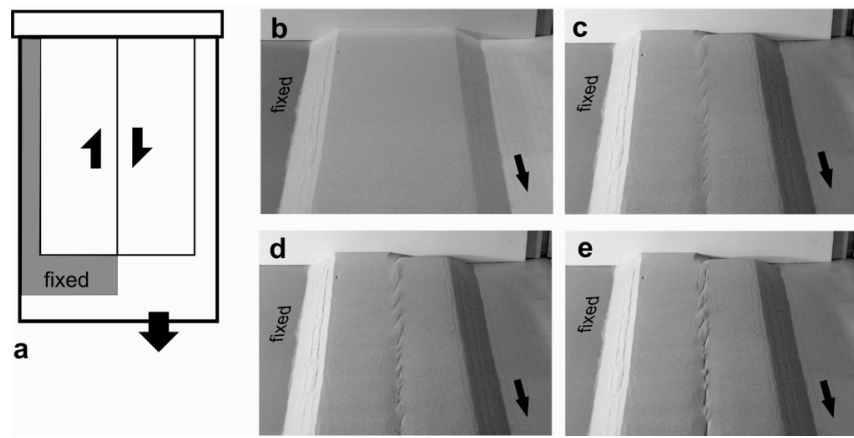

1

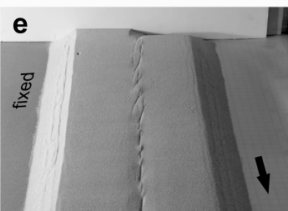

Fig. 3 a. Scheme for a model of a dextral strike slip fault, typically hundreds of kilometers long in nature. The most conspicuous major structures - in nature as well as in models - associated with wrench faults are regional systems of fractures approximately parallel with and commonly branching off from the master fault; $\mathbf{b} .0 \mathrm{~cm}$ offset,

$3 \mathrm{~cm}$ sandcake; c. $1 \mathrm{~cm}$ offset, first generation of Riedel shears

appear; d. $1.5 \mathrm{~cm}, 2$ nd and $3 \mathrm{rd}$ generation of Riedel shears

appear; e. more than $3 \mathrm{~cm}$ offset: $y$-shears and splays cut through the shear lenses.

\section{COMPRESSION - FOLD AND THRUST BELTS}

Shallow fold and thrust belts are found on the continental or "foreland" margins of virtually all present-day fold mountain belts (e. g. Canadian Rocky Mountains Stöckli et al., 2003; Zagros Fold Belt - Berberian, 1995; Alps - Schmid et al., 2004 and Jura Mountains - Becker, 2000). In the European Alps, hundreds of years of detailed geological work have concentrated on elucidating the largescale structures. However, one of the general observed effects was the fact that nappe stacking in orogenic belts like the Alps began at top and ended at the bottom of the nappe pile - a very complex situation in nature, which is easy to model with the sandbox (Fig. 4).
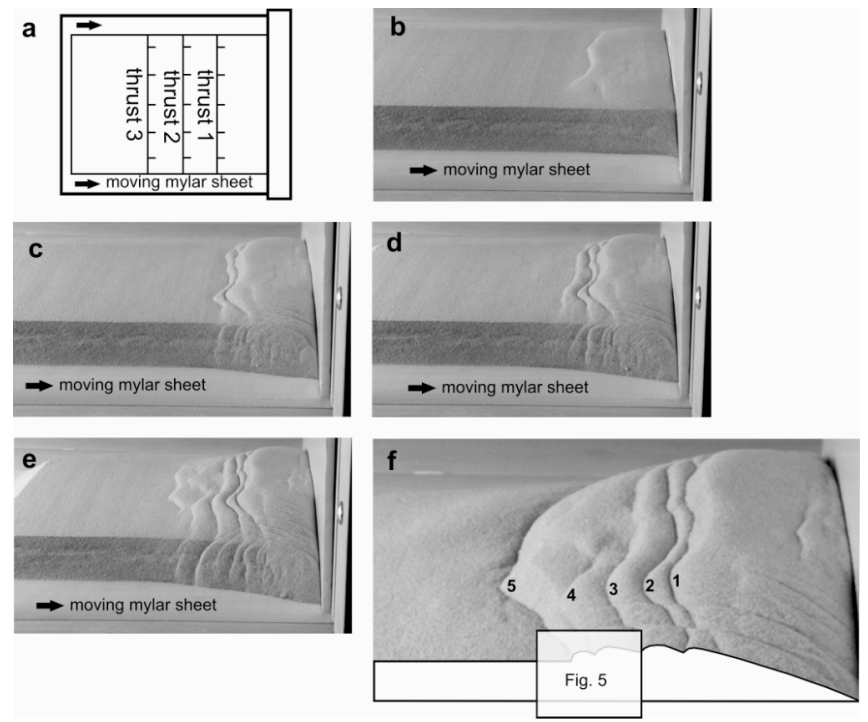

Fig. 4 a. Scheme for a model of a fold-and-thrust belt, which produces convincing analogues concerning the sequence of nappe stacking from top to bottom and the overall geometry of the nappes; b. $3 \mathrm{~cm}$ sandcake, $0.5 \mathrm{~cm}$ compression; c. $1.5 \mathrm{~cm}$ compression; d. $2 \mathrm{~cm}$ compression; e. $2.5 \mathrm{~cm}$ compression;

f. $3 \mathrm{~cm}$ compression, with numbered succession of thrusts.

These classic experiments with Lehner's sandbox are run by pulling the foil underneath the fixed backstop, resulting in bulk lateral shortening and thickening of the sandcake. On a crustal scale increase in vertical loading and crustal thickening would result in isostatic adjustment and depression of the basal decollement - a detail, which cannot be taken into account in the model. Anyway, the model is designed to focus on brittle deformation of the upper crust and the compressional experiments produce some perfect analogues concerning the sequence of activation of thrust faults and the overall geometry of the nappes (Fig. 5).

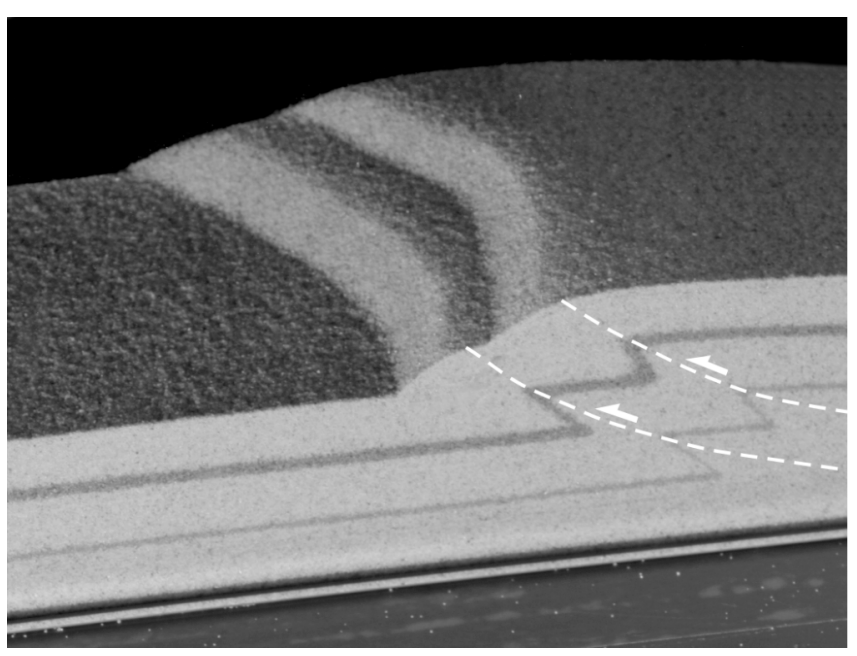

Fig. 5. An oblique view through frontal glass sidewall of the sandbox gives insight into an evolving fold-and-thrust belt (similar experimental scheme as in Fig. 4). In this case the box has been filled with sand of different colors.

\section{CONCLUSIONS}

In the geosciences, analogue sandbox models have proved to be a very powerful tool for studying structures and structural processes in nature. Such models offer cheap, concise data and allow the evolution of structures to be observed, leading to a better interpretation of structural systems. In a more educational context, students can be asked to carry out their own investigations, for example, by varying model parameters like thickness of the sandcake or use of different model materials, or to predict outcomes before the demonstrations take place. Anyway, the modelbuilder can control the boundary conditions and then compare the results of modeling with natural geological examples for improved conceptual visualization of the processes involved.

The simplicity and versatility of Lehner's sandbox enables the study of principal plate tectonic phenomena by means of experiments performed upon small scale models and is proposed for use in introductory geology courses.

\section{R E F E R E N C E S}

Becker, A. 2000, The Jura Mountains - an active foreland fold-and-thrust belt? Tectonophysics, 321: 381-406.

Berberian, M. 1995, Master "blind" thrust faults hidden under the Zagros folds; active basement tectonics and surface morphotectonics. Tectonophysics, 241: 193-224.

Braile, L.W., Keller, G.R., Wendlandt, R.F., Morgan, P. \& Khan, M.A. 1995, The East African rift system. In Continental Rifts: Evolution, Structure, Tectonics, Development (Olsen, K.H., ed.). Geotectonics, 23: 213-231.

Galazi G.G. 1993, The Origin of Lake Baikal. Lake Baikal Atlas. Moscow, p. 7.

Studia UBB, Geologia, 2009, 54 (1), 13 - 16 
Horner, J.T., Steyrer, H.P. 2005, An analogue model of a crustal scale fracture zone in west-central Mexico: evidence for a possible control of ore forming processes. Neues Jahrbuch für Geologie und Paläontologie, Abhandlungen, 236 (1/2): 185-206.

Horsfield, W.T. 1977, An experimental approach to basement-controlled faulting. Geologie en Mijnbouw, 56 (4): 363-370.

Hubbert M.K. 1937, Theory of scale models as applied to the study of geologic structures. Geological Society of America Bulletin, 48: 1459-1520.

Keller, G.R., Baldridge W.S. 1999, The Rio Grande rift. A geological and geophysical overview. Rocky Mountain Geology, 34 (1): 121-130.

Liu, H., McClay, K.R. \& Powell, D. 1992, Physical models of thrust wedges. In Thrust tectonics (McClay, K.R., Ed.), Chapman and Hall, London, p. 71-81.

Norris, R.J., Cooper, A.F. 2003, Very high strains recorded in mylonites along the Alpine Fault, New Zealand: implications for the deep structure of plate boundary faults. Journal of Structural Geology, 23: 507-520.

Olaussen, S., Larsen, B.T. \& Steel, R. 1994, The Upper Carboniferous-Permian Oslo rift; Basin fill in relation to tectonic development. In Pangea, Global environments and resources (Embry, A.F., Beauchamp, B. \& Glass, D.J., Eds.), Canadian. Society for Petrology and Geolology, Memoir, 17: 175-198.
Powell, R.E., Weldon, R.J., II \& Matti, J.C. 1993, The San Andreas fault system: Displacement, palinspastic reconstruction, and geologic evolution. Geological Society of America, Memoir, 178: 1-106.

Rotstein, Y., Edela, J.-B., Gabriel, G., Boulanger, D., Schaming, M. \& Munschy, M. 2006, Insight into the structure of the Upper Rhine Graben and its basement from a new compilation of Bouguer Gravity. Tectonophysics, 425 (1-4): 55-70.

Schmid, S.M., Fügenschuh, B., Kissling, E. \& Schuster, R. 2004, Tectonic map and overall architecture of the Alpine orogen. Eclogae Geologicae Helvetiae, 97, 93 p.

Şengör, A.M.C. 1979, The North Anatolian Transform Fault: its age, offset and tectonic significance. Journal of the Geological Society, London, 136: 269-282.

Stöckli, D.F., Dumitru, T.A., McWilliams, M.O. \& Farley, K.A. 2003, Cenozoic tectonic evolution of the White Mountains, California and Nevada. Geological Society of America Bulletin, 115: 788-816.

Steward, M.R. Strachan A.M., Martin, M.W. \& Holdsworth, R.E. 2001, Constraints on early sinistral displacements along the Great Glen Fault Zone, Scotland: structural setting, U-Pb geochronology and emplacement of the syn-tectonic Clunes tonalite. Journal of the Geological Society, 158: 821-830.

Storti, F., McClay K.R. 1995, Influence of syntectonic sedimentation on thrust wedges in analogue models. Geology, 23 (11): 999-1002. 